\title{
Adsorption properties of modified Saraca asoca bark powder towards $\mathrm{Ni}(\mathrm{II})$ ions
}

\author{
Mohammad Kashif Uddin \\ Department of Chemistry, College of Science, Majmaah University, Zulfi Campus, Al-Zulfi, 11932, Saudi Arabia
}

\begin{abstract}
.
In this present study, phosphate-modified Saraca asoca bark powder was used to bring out an efficient bioadsorbent for nickel (II) ion uptake from wastewater. The bioadsorbent was characterized using scanning electron microscopy and Fourier transform infrared spectroscopy. The effect of various parameters such as $\mathrm{pH}$, contact time, initial concentration and temperature were examined using the batch experimental process. The adsorption of nickel(II) was found to increase with the increase in concentration. The used bioadsorbent proved to be highly efficient and adsorbed $96 \%$ of nickel(II) from the aqueous solution at $\mathrm{pH}$ 4-6. The adsorption equilibrium data were described by using various isotherm models i.e. Langmuir, Freundlich, Temkin and Dubinin-Radhuskevic. Langmuir and pseudo-secondorder-kinetic were found to be best-fitted isotherm and kinetic models, respectively. Thermodynamic parameters showed the spontaneous and endothermic nature of the adsorption process. Succesful desorption of $\mathrm{Ni}(\mathrm{II})$ confirms the reusability of the bioadsorbent. The samples from real electroplating wastewater were collected to better examine the applicability of phosphate-modified Saraca asoca bark powder towards nickel(II) ions.
\end{abstract}

Keywords: bioadsorbent, desorption, isotherm, kinetics, modified plant material

\section{Introduction}

The existence of heavy metals in the water streams always is a potential health problem because of their noxiousness and non-biodegradable nature. Nickel, Ni (II), is the most common chemical element in the list of transition metals and found in small quantities in the environment. It used mainly to make stainless steel, coin, jewellery and other alloys. Ni (II) compounds are used in electroplating, pigment, chemical, mining and battery manufacturing industries (Cempel \& Nikel, 2006). Ni (II) is considered safe at low concentrations but when it increases in the environment, it has toxic effects on the ecosystem. As per world health organization (WHO) standards, the regulatory limit of $\mathrm{Ni}(\mathrm{II})$ in drinking water is $0.020 \mathrm{mg} / \mathrm{L}$ (Uddin, 2017). It is necessary to curb $\mathrm{Ni}$ (II) pollution in the environment and various technologies such as ion exchange resin (Tan et al., 2017), electrocoagulation (Djaenudin et al., 2018), membrane filtration (Borbély \& Nagy, 2009) have been developed for Ni (II) removal from wastewater but the highly used method is adsorption process (Malamis \& 
$11^{\text {th }}$ International Conference on Research in

SCIENCE \& TECHNOLOGY

14_16 May, 2021

Paris, France

Katsou, 2013). The biosorption process is the ability of biologically derived materials to adsorb the toxic aqueous pollutants. Both adsorption and biosorption are economically feasible methods and have many advantages in comparison to other available water treatment techniques (Kashif Uddin \& Fazul Rahaman, 2017). Chao et al. used three different agricultural wastes to prepare biosorbents for heavy metals removal in a fixed bed column (Chao et al., 2014). Activated carbon prepared from $\mathrm{H}_{3} \mathrm{PO}_{4}$ treated lotus stalks has been investigated for $\mathrm{Ni}$ (II) adsorption (Huang et al., 2011). The produced adsorbent was found to be highly porous with a surface area of $1220 \mathrm{~m}^{2} / \mathrm{g}$ and removed $\mathrm{Ni}$ (II) ion rapidly. TorabMostaedi et al. studied the biosorption of nickel with the uptake of $46.13 \mathrm{mg} / \mathrm{g}$ onto grapefruit peel and the recovery of $\mathrm{Ni}$ (II) was more than 97\% (Torab-Mostaedi et al., 2013). The binary and ternary adsorption system was used by Liu et al. for the adsorption of $\mathrm{Cd}(\mathrm{II}), \mathrm{Zn}$ (II) and $\mathrm{Ni}$ (II) ions using tourmaline and the study reported that multivalent solution at acidic $\mathrm{pH}$ values had a very good adsorption capacity for studied metal ions (Liu et al., 2013). Silica/activated carbon composite found to be very effective in the removal of $\mathrm{Ni}$ (II) at all studied concentrations (Karnib et al., 2014). The ash-palm thread which has a larger specific surface area and contained many active groups found to be quite an effective biosorbent for removing various heavy metals from wastewater (Lv et al., 2013). Characterisation revealed that an enormous quantity of active $\mathrm{SiO}_{2}$ was present in the basic structure of the palm thread and was responsible for high $\mathrm{Ni}(\mathrm{II})$ adsorption. Recently, modified dry duckweed (Qu et al., 2021), carbon-based adsorbents (Dhaouadi et al., 2021), chitosan derivative (Liakos et al., 2021), olive stone (Corral Bobadilla et al., 2020), fungal biomass (Sundararaju et al., 2020) and seaweed biomass (El-Naggar \& Rabei, 2020) are used as a natural adsorbent for Ni(II) removal.

Saraca asoca tree belongs to the Detarioideae subfamily and is commonly found in East Asian countries. Saraca asoca has antimicrobial, anticancer, antihemorrhagic and antimycotic properties (Pradhan et al., 2009). As an adsorbent, Saraca asoca has been successfully utilised to remove cationic dyes (Gupta et al., 2012) and lead ion (Goyal et al., 2008). The present work shows the adsorption efficiency of modified Saraca asoca and its potential role in $\mathrm{Ni}$ (II) removal from wastewater. This bioadsorbent is first time tested for $\mathrm{Ni}$ (II) adsorption in this study. The adsorptive performance, ease of availability, non-hazardous nature and low cost of Saraca asoca shows its significance for Ni(II) adsorption.

\section{Materials and Methods}

Saraca asoca is abundantly available in India and was collected, washed, dried and ground to powder size $(50-100 \mu \mathrm{m})$. The preapared bioadsorbent was then treated with a $50 \mathrm{~mL}$ of $0.1 \mathrm{~N}$ aqueous solution of trisodium phosphate dodecahydrate $\left(\mathrm{Na}_{3} \mathrm{PO}_{4} .12 \mathrm{H}_{2} \mathrm{O}\right)$ for $24 \mathrm{hrs}$. After washed several times by deionized water, its dried form was used as a phosphate modified bioadsorbent for $\mathrm{Ni}(\mathrm{II})$ ion. Nickel nitrate, $\mathrm{Ni}\left(\mathrm{NO}_{3}\right)_{2}$, of analytical reagent grade in its necessary amount, was used to prepare the $\mathrm{Ni}$ (II) solution for adsorption experiments. The \% adsorption of $\mathrm{Ni}$ (II) was increased from 80 to $95 \%$ after phosphate and therefore, it was chosen for further studies. The modified bioadsorbent was characterized by scanning electron microscopy (SEM) and Fourier transform infrared spectroscopy (FTIR) techniques to observe 
14_16 May, 2021

Paris, France

the morphology and functional groups of Saraca asoca prior and subsequent $\mathrm{Ni}$ (II) adsorption.

\subsection{Adsorption experiments}

The adsorption experiments were conducted by the batch process. The amount of $0.5 \mathrm{gm}$ bioadsorbent was dispersed in $50 \mathrm{~mL} \mathrm{Ni(II)} \mathrm{solution} \mathrm{and} \mathrm{the} \mathrm{combined} \mathrm{solution} \mathrm{was} \mathrm{stirred,}$ filtered and analysed to determine the final concentration of $\mathrm{Ni}$ (II) ion by atomic absorption spectrophotometer. The following formula was used to calculate the \% Ni(II) adsorption:

$$
\% \text { adsorption }=\frac{\text { Concentration }_{\text {initial }}-\text { Concentration }_{\text {final }}}{\text { Concentration }_{\text {initial }}} \times 100
$$

The effect of various $\mathrm{pH}$ ranges $(\mathrm{pH} 2-\mathrm{pH} 9)$ on $\mathrm{Ni}$ (II) adsorption was tested. The $\mathrm{pH}$ was regulated by adding $0.1 \mathrm{M} \mathrm{HCl}$ or $\mathrm{NaOH}$ solution. The point of zero charge (pzc) of the bioadsorbent was also noted. The effect of various contact time intervals (1- $120 \mathrm{~min})$, concentration levels $(10-100 \mathrm{mg} / \mathrm{L})$ and temperatures $\left(30-50^{\circ} \mathrm{C}\right)$ were also determined by the process as described earlier.

\section{2..1.1 Breakthrough and desorption experiments}

In a breakthrough study, a glass column is used in which $0.5 \mathrm{gm}$ of bioadsorbent was put onto the glass wool support and then $1000 \mathrm{~mL}$ of $50 \mathrm{mg} / \mathrm{L} \mathrm{Ni(II)} \mathrm{solution} \mathrm{was} \mathrm{distributed} \mathrm{over} \mathrm{it} \mathrm{at}$ the periodic interval of $1 \mathrm{~mL} / \mathrm{min}$. The $50 \mathrm{~mL}$ run-off was collected firstly in $10 \mathrm{~mL}$ fractions. The samples were then analyzed for $\mathrm{Ni}$ (II) concentration. $50 \mathrm{~mL}$ of $0.1 \mathrm{M} \mathrm{HCl}$ was used as a desorbing agent for desorption experiments.

\section{Results and discussion}

\subsection{Characterization of bioadsorbent}

SEM images display the porous honeycomb-like structure with large holes present on the surface of modified Saraca asoca bioadsorbent (Fig. 1a). The surface seems smooth and offers more support to the adsorption movement of $\mathrm{Ni}$ (II) over it. Fig. 1b clearly shows the effective accumulation of $\mathrm{Ni}(\mathrm{II})$ as the holes were successfully filled by $\mathrm{Ni}$ (II) and the surface became extremely bright after $\mathrm{Ni}$ (II) deposition on it.

The peaks at 3,427-3435 $\mathrm{cm}^{-1}$ in FTIR spectra (Fig. 2, ab) were assigned to the hydroxyl ($\mathrm{OH}$ ) group due to inter and intramolecular attractive forces (Rao \& Kashifuddin, 2014). These -OH stretching vibrations indicate the occurrence of a free $\mathrm{OH}$ group and carboxylic acid (Gnanasambandam, 2000). A peak at $3786 \mathrm{~cm}^{-1}$ in modified bioadsorbent corresponds to the -OH group of $\mathrm{PO}_{4}{ }^{3-}$ (Arai \& Sparks, 2001). Most peaks in both the spectra almost occurred at 
$11^{\text {th }}$ International Conference on Research in SCIENCE \& TECHNOLOGY

14_16 May, 2021

Paris, France

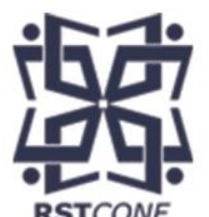

the same place, however, some shifting in the peaks can be observed. A peak as present in bioadsorbent at $1450 \mathrm{~cm}^{-1}$ belongs to carboxylate group was loosened to $1423.6 \mathrm{~cm}^{-1}$ after $\mathrm{Ni}$ (II) adsorption representing the strong interface of $\mathrm{Ni}(\mathrm{II})$ with the modified bioadsorbent. Another peak that appeared at $1157 \mathrm{~cm}^{-1}$ belongs to the cyano group $(\mathrm{C} \equiv \mathrm{N})$. After adsorption, it was shifted to $1180 \mathrm{~cm}^{-1}$ which suggests the presence of nickel compound. The peaks at $1023 \mathrm{~cm}^{-1}$ indicative of carbonyl and carboxyl groups which may have a part in the adsorption mechanism (El-Sadaawy \& Abdelwahab, 2014).

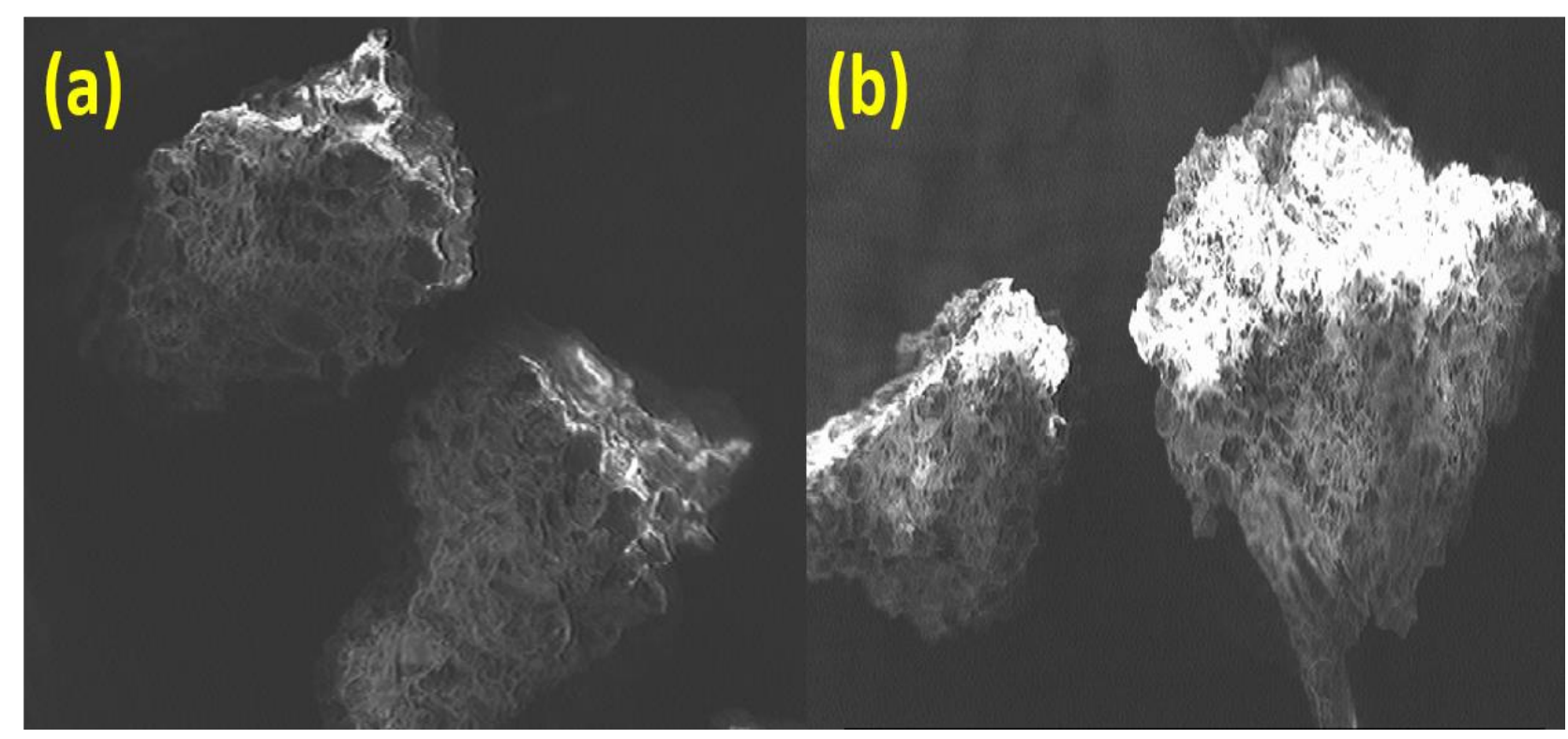

Figure 1: SEM images of modified biaosdorbent (a) and Ni(II) adorsbed modified bioadsorbent (b) 
14_16 May, 2021

Paris, France
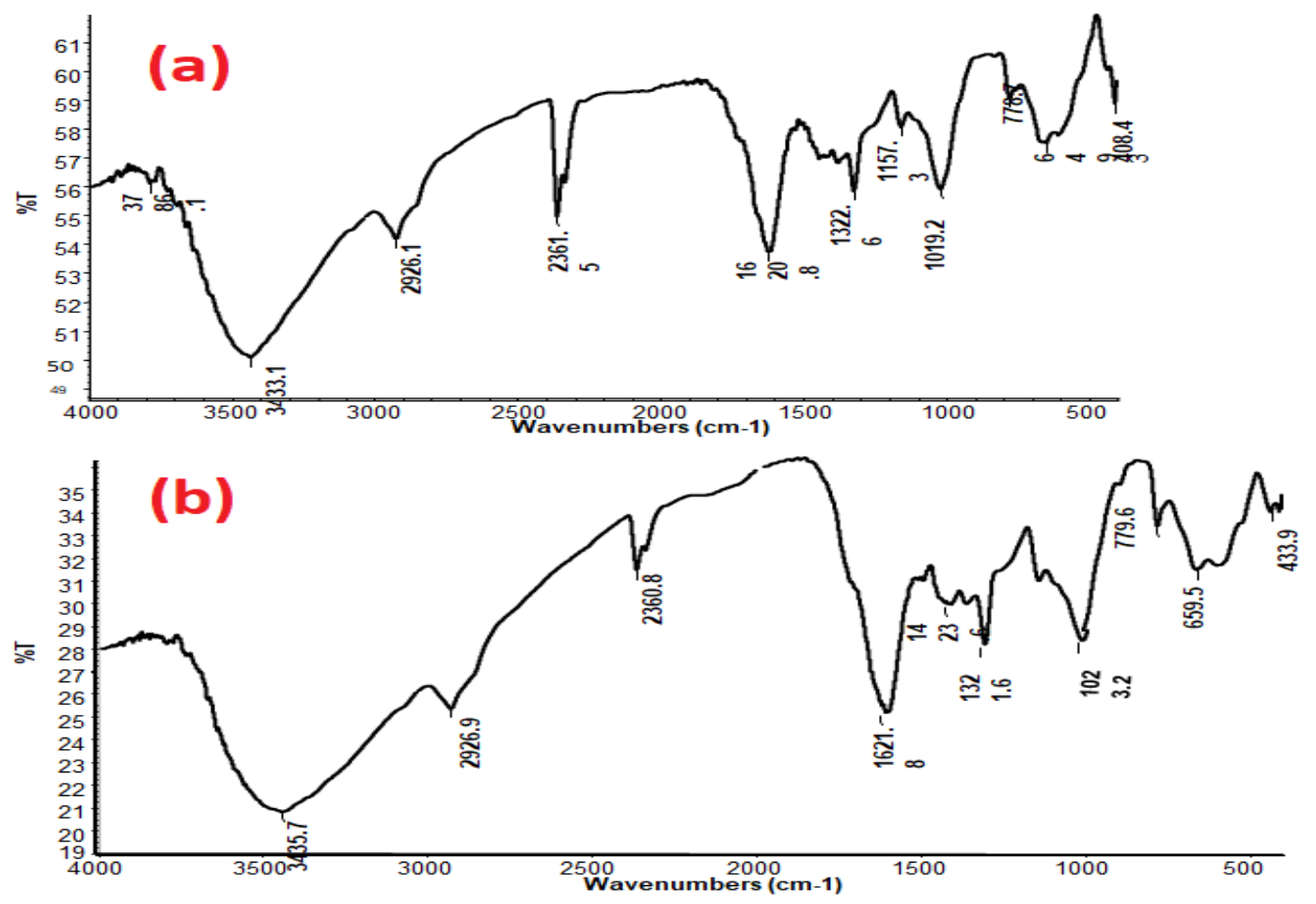

Figure 2: FTIR spectra of modified biaosdorbent (a) and Ni(II) adorsbed modified bioadsorbent $(b$ 入

\subsubsection{Adsorption experiments}

Fig. 3a shows that with the increase in $\mathrm{Ni}(\mathrm{II})$ concentrations $(10-100 \mathrm{mg} / \mathrm{L})$, the uptake capacity of the bioadsorbent was also increased $(0.99-7.90 \mathrm{mg} / \mathrm{g})$. The equilibrium adsorption capacities at 10-100 mg/L Ni(II) concentrations were found to be $0.99,1.97,4.42,6.85$ and $7.90 \mathrm{mg} / \mathrm{g}$, respectively This increase is obvious because, with the rise in concentration, the formation of the bond between the Ni(II) compound and bioadsorbent improved. To know the effect of $\mathrm{pH}$ values (2-9) on the \% adsorption, a series of experiments were carried out. Fig. $3 \mathrm{~b}$ shows that the adsorption of $\mathrm{Ni}(\mathrm{II})$ was intensely exaggerated by $\mathrm{pH}$ values. At $\mathrm{pH} 2$, $75.4 \%$ adsorption was recorded and then the value increased by an increase in $\mathrm{pH}$ up to $96 \%$ at $\mathrm{pH}$ 4. This rise was because at $\mathrm{pH}<6$, nickel ion existed as $\mathrm{Ni}^{2+}$ while the decline of $\%$ adsorption at low $\mathrm{pH}$ values was because of the struggle between $\mathrm{Ni}$ (II) and $\mathrm{H}^{+}$for binding sites on the bioadsorbent surface. At $\mathrm{pH}>6$, the nickel got precipitated because, at high $\mathrm{pH}$ values, $\mathrm{Ni}(\mathrm{OH})_{2}, \mathrm{Ni}(\mathrm{OH})_{3}$ are the dominant species (Jalali \& Najafi, 2018) that reduce the solubility of the metal and cause precipitation. 


\section{$11^{\text {th }}$ International Conference on Research in SCIENCE \& TECHNOLOGY}

14_16 May, 2021

Paris, France
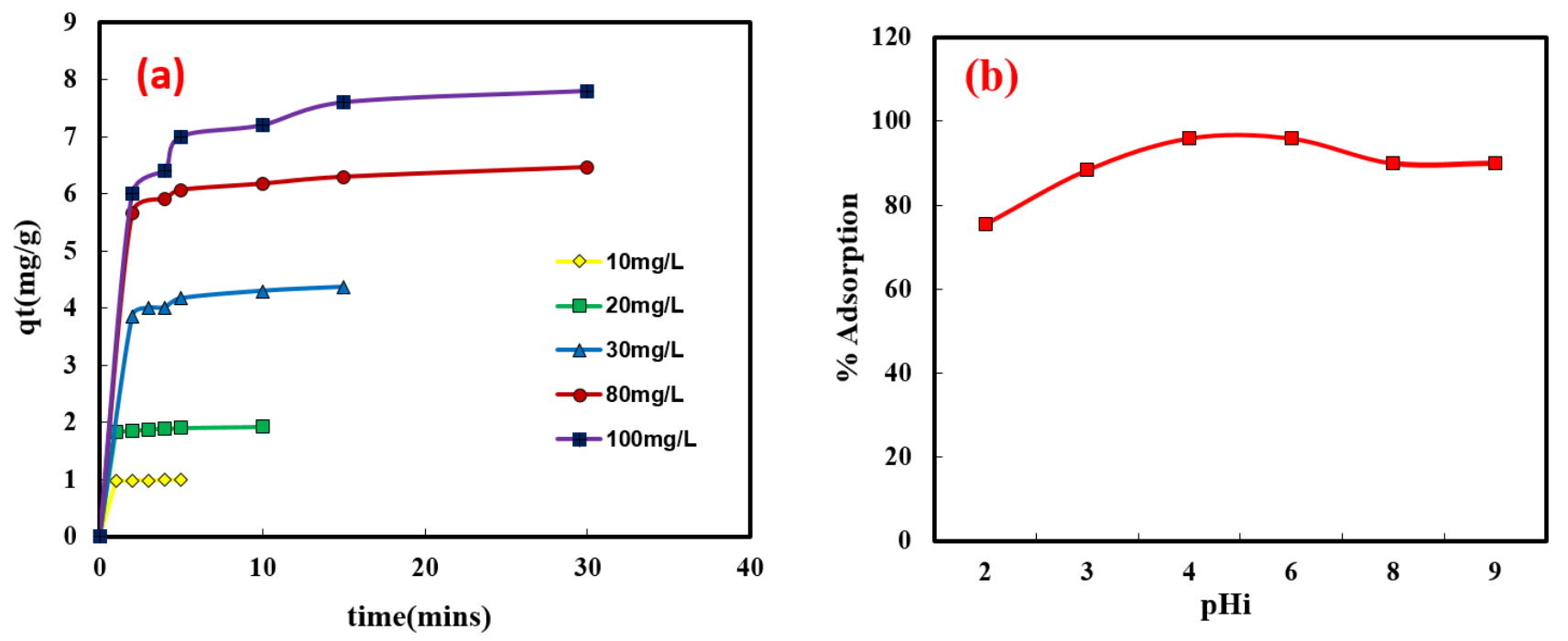

Langmuir, Freundlich, Temkin and Dubinin-Radushkeuich isotherm models were used to adequate the experimental data as obtained at various temperatures. Table 1 shows the linear forms of the applied isotherm models while Table 2 shows the adsorption isotherm results. The linear fitting of data and high $\mathrm{R}^{2}$ values confirmed the monolayer and homogenous distribution of $\mathrm{Ni}$ (II) on the bioadsorbent. The calculated values of mean free energy (E) are in the range of $9-11 \mathrm{~kJ} / \mathrm{mol}$ indicate that adsorption was chemical. Table 3 shows the comparison of maximum adsorption capacity of phosphate-modified saraca asoca with other plant-based natural adsorbents as reported earlier. The results prove its effectiveness as a bioadsorbent for the removal of $\mathrm{Ni}(\mathrm{II})$ from the aqueous solution.

Table 1 Linear equations and various adsorption isotherm parameters for the adsorption of Ni(II) on phosphatemodified bioadsorbent

\begin{tabular}{|l|l|}
\hline Isotherm model & Linear equation \\
\hline Langmuir & $\frac{1}{\mathrm{q}_{\mathrm{e}}}=\frac{1}{\mathrm{q}_{\mathrm{m}} \times \mathrm{b}} \times \frac{1}{\mathrm{C}_{\mathrm{e}}}+\frac{1}{\mathrm{q}_{\mathrm{m}}}$ \\
& Where b refers to Langmuir constant \\
\hline Freundlich & $\log \mathrm{q}_{\mathrm{e}}=\log \mathrm{K}+\frac{1}{\mathrm{n}} \log \mathrm{C}_{\mathrm{e}}$ \\
& Where K refers to Freundlich constant \\
\hline
\end{tabular}




\section{$11^{\text {th }}$ International Conference on Research in SCIENCE \& TECHNOLOGY}

14_16 May, 2021

Paris, France

\begin{tabular}{|l|l|}
\hline Temkin & $\begin{array}{c}q_{e}=\left(\frac{R T}{b}\right) \times \ln A t+\left(\frac{R T}{b}\right) \times \ln C_{e} \\
\text { Where }(\mathrm{RT} / \mathrm{b})=\mathrm{B}_{\mathrm{t}}, \mathrm{R} \text { is a gas constant, } \mathrm{T} \text { is } \\
\text { temperature, } \mathrm{A}_{\mathrm{t}} \text { and } \mathrm{B}_{\mathrm{t}} \text { are Temkin constants. }\end{array}$ \\
\hline D-R & $\begin{array}{l}\ln q e=\ln q_{d r}-\beta \varepsilon^{2} \\
\text { Where } \beta \text { is a D-R constant which gives mean } \\
\text { free energy }(\mathrm{E}) \text { which can be find by following } \\
\text { relattion: }\end{array}$ \\
& $\begin{array}{l}\varepsilon=R T \ln \left(1+\frac{1}{c e}\right) \\
\end{array}$ \\
\hline
\end{tabular}

Table 2 Adsorption isotherm results for the adsorption of Ni(II) on phosphate-modified bioadsorbent

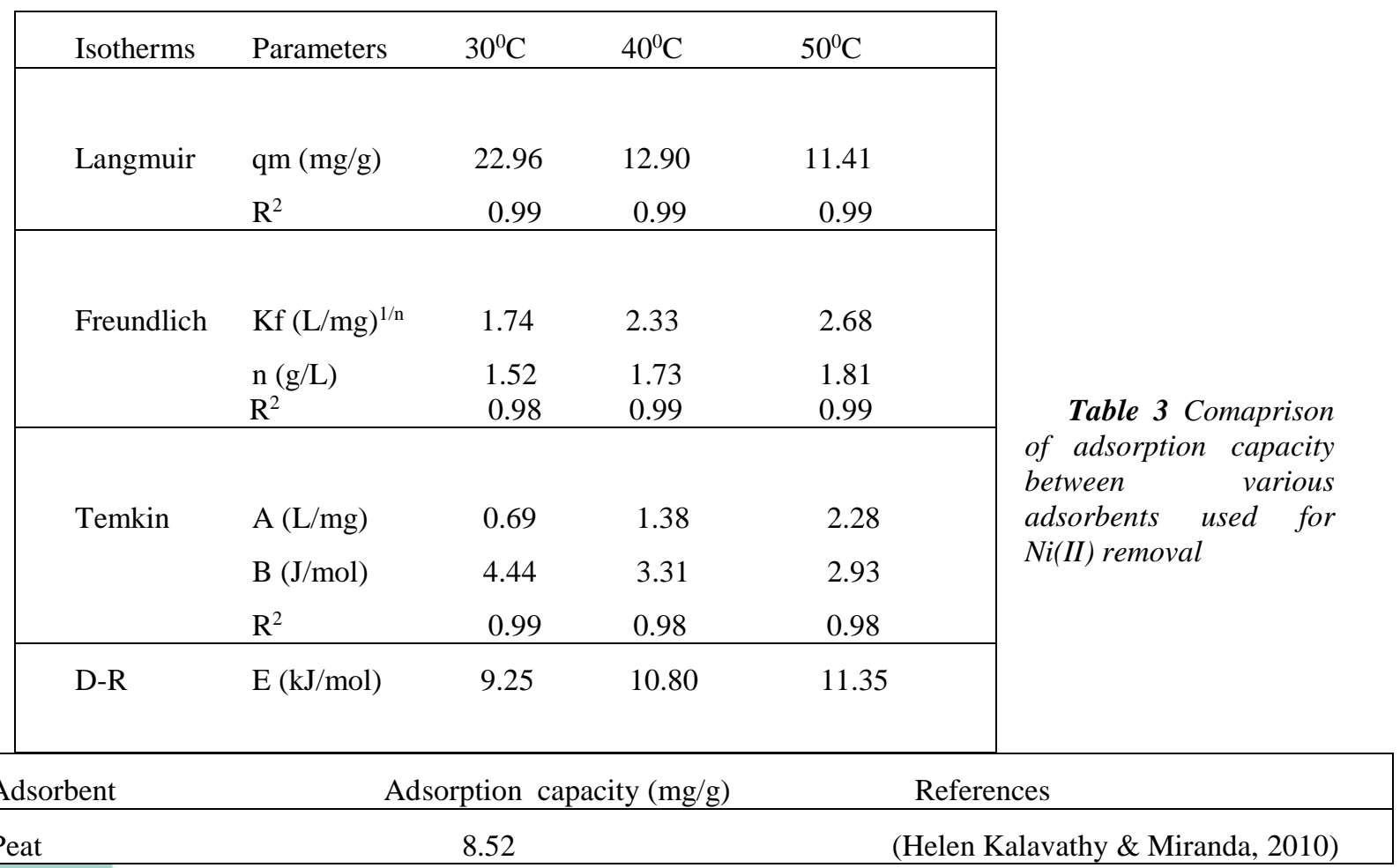




\section{$11^{\text {th }}$ International Conference on Research in SCIENCE \& TECHNOLOGY}

14_16 May, 2021

Paris, France

\begin{tabular}{|lrl|}
\hline Modified pine bark & 9.50 & (Argun et al., 2009) \\
Wheat Straw & 7.90 & (Hajahmadi et al., 2015) \\
Coir pith & 9.50 & (Ewecharoen et al., 2008) \\
Activated carbon & 4.52 & (Kavand et al., 2016) \\
Orange peel & 9.82 & (Feng et al., 2011) \\
Tea factory waste & 15.26 & (MALKOC \& NUHOGLU, 2005) \\
Grape stalks waste & 10.66 & (Villaescusa et al., 2004) \\
Beech sawdust & 4.50 & (Božić et al., 2013) \\
Banana peel & 6.80 & (Annadurai et al., 2003) \\
Hazelnut shell & 10.10 & (Demirbas, 2002) \\
Alternanthera Philoxeroides biomass & 9.73 & (Wang \& Qin, 2006) \\
Doum-palm seed coat & 4.93 & (El-Sadaawy \& Abdelwahab, 2014) \\
Phosphate-modified saraca asoca & 22.90 & Present study \\
& & \\
\hline
\end{tabular}

Thermodynamic parameters such as free energy change $(\Delta \mathrm{G})$, enthalpy change $(\Delta \mathrm{H})$ and entropy change $(\Delta S)$ were calculated using the following relations:

$$
\begin{aligned}
& K c=\frac{C_{\text {adsorption }}}{C_{\text {equlibrium }}} \\
& \Delta G=-R T \ln K c \\
& \ln K c=-\frac{\Delta H}{R T}+\frac{\Delta S}{R}
\end{aligned}
$$

The positive value of $\Delta \mathrm{H}$ indicates that the adsorption process was endothermic, the negative values of $\Delta \mathrm{G}$ affirm the feasible $\mathrm{Ni}$ (II) adsorption while the positive value of $\Delta \mathrm{S}$ specifies greater randomness on the bioadsorbent's surface (Table 4).

Table 4 Adsorption thermodynamic results for the adsorption of $\mathrm{Ni}(I I)$ on phosphate-modified bioadsorbent

\begin{tabular}{|cccccc|}
\hline $\begin{array}{c}\text { Temperature } \\
\left({ }^{\circ} \mathrm{C}\right)\end{array}$ & $\mathrm{Kc}$ & $\begin{array}{c}\Delta \mathrm{G} \\
(\mathrm{kJ} / \mathrm{mol})\end{array}$ & $\begin{array}{c}\Delta \mathrm{H} \\
(\mathrm{kJ} / \mathrm{mol})\end{array}$ & $\begin{array}{c}\Delta \mathrm{S} \\
(\mathrm{kJ} / \mathrm{mol} / \mathrm{K})\end{array}$ & $\mathrm{R}^{2}$ \\
\hline 30 & 19.00 & -7.42 & 55.59 & 12.47 & 0.97 \\
40 & 30.30 & -8.87 & & & \\
\hline
\end{tabular}




\section{$11^{\text {th }}$ International Conference on Research in SCIENCE \& TECHNOLOGY}

14_16 May, 2021

Paris, France
50
40.70
$-9.95$

Table 5 shows the data of the parameters as obtained by kinetic study. The high correlation coefficients $\left(\mathrm{R}^{2}\right)$ and the close values of calculated adsorption capacity (qe $\left.\mathrm{q}_{\text {cal }}\right)$ and experimental adsorption capacity (qe $\mathrm{exp}_{\text {) }}$ confirm that the pseudo-second model was better employed with adsorption results.

Table 5 Adsorption kinetic results for the adsorption of Ni(II) on phosphate-modified bioadsorbent

\begin{tabular}{|c|c|c|c|c|c|c|c|c|}
\hline \multirow{2}{*}{$\begin{array}{l}\text { Concentration } \\
(\mathrm{mg} / \mathrm{L})\end{array}$} & \multicolumn{5}{|c|}{ Pseudo-first-order } & \multicolumn{2}{|c|}{ Pseudo-second-order } & \multirow[b]{2}{*}{$\mathrm{R}^{2}$} \\
\hline & $\begin{array}{l}\mathrm{q}_{\mathrm{e}} \\
(\mathrm{exp}) \\
(\mathrm{mg} / \mathrm{g})\end{array}$ & $\begin{array}{c}\mathrm{q}_{\mathrm{e}} \\
(\mathrm{cal}) \\
(\mathrm{mg} / \mathrm{g}\end{array}$ & $\begin{array}{c}\mathrm{K}_{1} \\
\left(\mathrm{~mol} / \mathrm{L}^{\prime} \mathrm{s}\right) \\
\end{array}$ & $\mathrm{R}^{2}$ & $\begin{array}{l}\mathrm{q}_{\mathrm{e}} \\
(\mathrm{cal}) \\
(\mathrm{mg} / \mathrm{g}) \\
\end{array}$ & $\left(\mathrm{g} / \mathrm{mg}^{/} \mathrm{min}\right)$ & $\begin{array}{c}\mathrm{h} \\
(\mathrm{mg} / \mathrm{g} / \mathrm{min})\end{array}$ & \\
\hline 10 & 0.99 & 0.05 & 0.74 & 0.86 & 0.99 & 28.36 & 27.80 & 1.00 \\
\hline 40 & 1.97 & 0.14 & 0.10 & 0.95 & 1.98 & 10.20 & 40.00 & 0.99 \\
\hline 50 & 4.42 & 2.14 & 0.05 & 0.90 & 4.43 & 0.60 & 11.83 & 0.99 \\
\hline 80 & 6.85 & 1.05 & 0.03 & 0.90 & 6.54 & 0.32 & 15.46 & 0.99 \\
\hline 100 & 7.90 & 1.96 & 0.10 & 0.95 & 8.00 & 0.14 & 9.20 & 0.99 \\
\hline
\end{tabular}

\subsubsection{Desorption, Breakthrough curve and application to electroplating wastewater}

Fig. 8 shows the breakthrough point that occurred after passing $50 \mathrm{~mL} \mathrm{Ni(II)} \mathrm{and} \mathrm{the}$ breakthrough and exhaustive capacities were 5 and $65 \mathrm{mg} / \mathrm{g}$, respectively. The desorption results showed that $99.1 \% \mathrm{Ni}$ (II) amount was recuperated which indicate that modified bioadsorbent can be used frequently. The electroplating wastewater was also collected and analysed. The presence of several cations $\left(\mathrm{Na}^{+}, \mathrm{K}^{+}, \mathrm{Ca}^{2+}\right)$, and metal ions $\left(\mathrm{Cu}^{2+}, \mathrm{Zn}^{2+}, \mathrm{Ni}^{2+}\right)$ was found in it. After using saraca asoca bioadsorbent, almost $70 \% \mathrm{Ni}$ (II) was removed which shows that even with the existence of other pollutants, the bioadsorbent worked well. 
$11^{\text {th }}$ International Conference on Research in

SCIENCE \& TECHNOLOGY

14_16 May, 2021

Paris, France

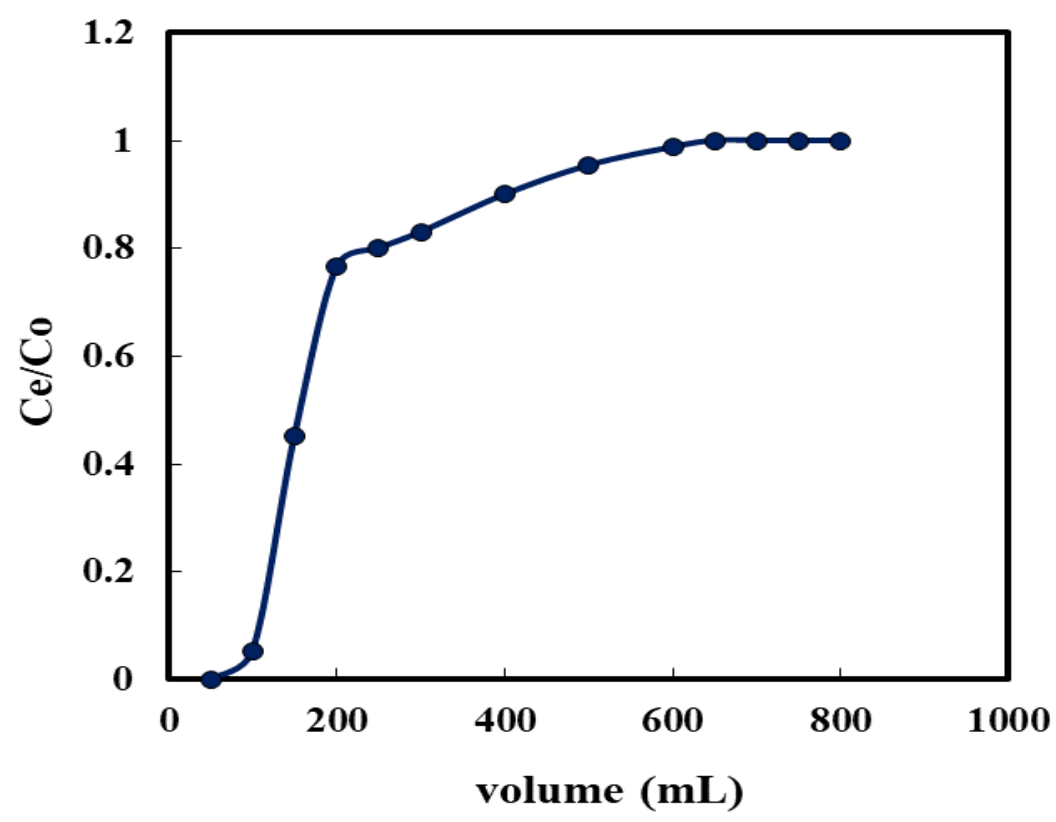

\section{Conclusion}

The adsorption of $\mathrm{Ni}$ (II) from contaminated water by saroca asoca bioadsorbent was examined. The adsorption outcomes verified that the maximum removal was found at $\mathrm{pH}$ 4-6. The adsorption was best reported by the pseudo-second-order kinetic model and was perfectly fitted by the Langmuir isotherm. The adsorption processes were endothermic. The obtained results indicate that the biomass has highly useful in $\mathrm{Ni}(\mathrm{II})$ adsorption and can be reused and applied as a promising nontoxic material.

\section{References}

Annadurai, G., Juang, R. S., \& Lee, D. J. (2003). Adsorption of heavy metals from water using banana and orange peels. Water Science and Technology, 47(1), 185-190. https://doi.org/10.2166/wst.2003.0049

Arai, Y., \& Sparks, D. L. (2001). ATR-FTIR Spectroscopic Investigation on Phosphate Adsorption Mechanisms at the Ferrihydrite-Water Interface. Journal of Colloid and Interface Science, 241(2), 317-326. https://doi.org/10.1006/jcis.2001.7773

Argun, M. E., Dursun, S., \& Karatas, M. (2009). Removal of Cd(II), Pb(II), Cu(II) and Ni(II) from water using modified pine bark. Desalination, 249(2), 519-527. https://doi.org/10.1016/j.desal.2009.01.020

Borbély, G., \& Nagy, E. (2009). Removal of zinc and nickel ions by complexation-membrane 
$11^{\text {th }}$ International Conference on Research in

SCIENCE \& TECHNOLOGY

14_16 May, 2021

Paris, France

filtration process from industrial wastewater. Desalination, 240(1-3), 218-226. https://doi.org/10.1016/j.desal.2007.11.073

Božić, D., Gorgievski, M., Stanković, V., Štrbac, N., Šerbula, S., \& Petrović, N. (2013). Adsorption of heavy metal ions by beech sawdust - Kinetics, mechanism and equilibrium of the process. Ecological Engineering, 58, 202-206. https://doi.org/10.1016/j.ecoleng.2013.06.033

Cempel, M., \& Nikel, G. (2006). Nickel: A Review of Its Sources and Environmental Toxicology. Polish Journal of Environmental Studies, 15(3).

Chao, H.-P., Chang, C.-C., \& Nieva, A. (2014). Biosorption of heavy metals on Citrus maxima peel, passion fruit shell, and sugarcane bagasse in a fixed-bed column. Journal of Industrial and Engineering Chemistry, 20(5), 3408-3414. https://doi.org/10.1016/j.jiec.2013.12.027

Corral Bobadilla, M., Lostado Lorza, R., Somovilla Gómez, F., \& Escribano García, R. (2020). Adsorptive of Nickel in Wastewater by Olive Stone Waste: Optimization through Multi-Response Surface Methodology Using Desirability Functions. Water, 12(5), 1320. https://doi.org/10.3390/w12051320

Demirbas, E. (2002). Removal of Ni(II) from aqueous solution by adsorption onto hazelnut shell activated carbon: equilibrium studies. Bioresource Technology, 84(3), 291-293. https://doi.org/10.1016/S0960-8524(02)00052-4

Dhaouadi, F., Sellaoui, L., Reynel-Ávila, H. E., Landín-Sandoval, V., Mendoza-Castillo, D. I., Jaime-Leal, J. E., Lima, E. C., Bonilla-Petriciolet, A., \& Lamine, A. Ben. (2021). Adsorption mechanism of $\mathrm{Zn} 2+, \mathrm{Ni} 2+, \mathrm{Cd} 2+$, and $\mathrm{Cu} 2+$ ions by carbon-based adsorbents: interpretation of the adsorption isotherms via physical modelling. Environmental Science and Pollution Research. https://doi.org/10.1007/s11356-02112832-x

Djaenudin, Muchlis, \& Ardeniswan. (2018). Nickel removal from electroplating wastewater using electrocoagulation. IOP Conference Series: Earth and Environmental Science, 160, 012016. https://doi.org/10.1088/1755-1315/160/1/012016

El-Naggar, N. E.-A., \& Rabei, N. H. (2020). Bioprocessing optimization for efficient simultaneous removal of methylene blue and nickel by Gracilaria seaweed biomass. Scientific Reports, 10(1), 17439. https://doi.org/10.1038/s41598-020-74389-y

El-Sadaawy, M., \& Abdelwahab, O. (2014). Adsorptive removal of nickel from aqueous solutions by activated carbons from doum seed (Hyphaenethebaica) coat. Alexandria Engineering Journal, 53(2), 399-408. https://doi.org/10.1016/j.aej.2014.03.014

Ewecharoen, A., Thiravetyan, P., \& Nakbanpote, W. (2008). Comparison of nickel adsorption from electroplating rinse water by coir pith and modified coir pith. Chemical Engineering Journal, 137(2), 181-188. https://doi.org/10.1016/j.cej.2007.04.007

Feng, N., Guo, X., Liang, S., Zhu, Y., \& Liu, J. (2011). Biosorption of heavy metals from aqueous solutions by chemically modified orange peel. Journal of Hazardous Materials, 
$11^{\text {th }}$ International Conference on Research in

SCIENCE \& TECHNOLOGY

14_16 May, 2021

Paris, France

185(1), 49-54. https://doi.org/10.1016/j.jhazmat.2010.08.114

Gnanasambandam, R. (2000). Determination of pectin degree of esterification by diffuse reflectance Fourier transform infrared spectroscopy. Food Chemistry, 68(3), 327-332. https://doi.org/10.1016/S0308-8146(99)00191-0

Goyal, P., Sharma, P., Srivastava, S., \& Srivastava, M. M. (2008). Saraca indica leaf powder for decontamination of $\mathrm{Pb}$ : removal, recovery, adsorbent characterization and equilibrium modeling. International Journal of Environmental Science \& Technology, 5(1), 27-34. https://doi.org/10.1007/BF03325994

Gupta, N., Kushwaha, A. K., \& Chattopadhyaya, M. C. (2012). Adsorption studies of cationic dyes onto Ashoka (Saraca asoca) leaf powder. Journal of the Taiwan Institute of Chemical Engineers, 43(4), 604-613. https://doi.org/10.1016/j.jtice.2012.01.008

Hajahmadi, Z., Younesi, H., Bahramifar, N., Khakpour, H., \& Pirzadeh, K. (2015). Multicomponent isotherm for biosorption of $\mathrm{Zn}(\mathrm{II}), \mathrm{CO}$ (II) and $\mathrm{Cd}(\mathrm{II})$ from ternary mixture onto pretreated dried Aspergillus niger biomass. Water Resources and Industry, 11, 71-80. https://doi.org/10.1016/j.wri.2015.07.003

Helen Kalavathy, M., \& Miranda, L. R. (2010). Moringa oleifera-A solid phase extractant for the removal of copper, nickel and zinc from aqueous solutions. Chemical Engineering Journal, 158(2), 188-199. https://doi.org/10.1016/j.cej.2009.12.039

Huang, L., Sun, Y., Yang, T., \& Li, L. (2011). Adsorption behavior of Ni (II) on lotus stalks derived active carbon by phosphoric acid activation. Desalination, 268(1-3), 12-19. https://doi.org/10.1016/j.desal.2010.09.044

Jalali, M., \& Najafi, S. (2018). Effect of pH on Potentially Toxic Trace Elements (Cd, Cu, Ni, and Zn) Solubility in Two Native and Spiked Calcareous Soils: Experimental and Modeling. Communications in Soil Science and Plant Analysis, 49(7), 814-827. https://doi.org/10.1080/00103624.2018.1435682

Karnib, M., Kabbani, A., Holail, H., \& Olama, Z. (2014). Heavy Metals Removal Using Activated Carbon, Silica and Silica Activated Carbon Composite. Energy Procedia, 50, 113-120. https://doi.org/10.1016/j.egypro.2014.06.014

Kashif Uddin, M., \& Fazul Rahaman, P. (2017). A study on the potential applications of rice husk derivatives as useful adsorptive material. In Inorganic Pollutants in Wastewater (pp. 149-186). https://doi.org/10.21741/9781945291357-4

Kavand, M., Soleimani, M., Kaghazchi, T., \& Asasian, N. (2016). Competitive Separation of Lead, Cadmium, and Nickel from Aqueous Solutions Using Activated Carbon: Response Surface Modeling, Equilibrium, and Thermodynamic Studies. Chemical Engineering Communications, 203(1), 123-135. https://doi.org/10.1080/00986445.2014.962691

Liakos, E. V., Mone, M., Lambropoulou, D. A., Bikiaris, D. N., \& Kyzas, G. Z. (2021). Adsorption Evaluation for the Removal of Nickel, Mercury, and Barium Ions from Single-Component and Mixtures of Aqueous Solutions by Using an Optimized Biobased Chitosan Derivative. Polymers, 13(2), 232. https://doi.org/10.3390/polym13020232 
$11^{\text {th }}$ International Conference on Research in

SCIENCE \& TECHNOLOGY

14_16 May, 2021

Paris, France

Liu, H., Wang, C., Liu, J., Wang, B., \& Sun, H. (2013). Competitive adsorption of Cd(II), $\mathrm{Zn}$ (II) and $\mathrm{Ni}$ (II) from their binary and ternary acidic systems using tourmaline. Journal of Environmental Management, $128, \quad 727-734$. https://doi.org/10.1016/j.jenvman.2013.06.024

Lv, W., He, B., Zhou, Y., \& Lu, J. (2013). Adsorption of Ni(II), Cd(II) and Cr(III) on the Palm Thread Ash Burned at Low Temperature. Asian Journal of Chemistry, 25(13), 7139-7144.

Malamis, S., \& Katsou, E. (2013). A review on zinc and nickel adsorption on natural and modified zeolite, bentonite and vermiculite: Examination of process parameters, kinetics and isotherms. Journal of Hazardous Materials, 252-253, 428-461. https://doi.org/10.1016/j.jhazmat.2013.03.024

MALKOC, E., \& NUHOGLU, Y. (2005). Investigations of nickel(II) removal from aqueous solutions using tea factory waste. Journal of Hazardous Materials, 127(1-3), 120-128. https://doi.org/10.1016/j.jhazmat.2005.06.030

Pradhan, P., Joseph, L., Gupta, V., Chulet, R., Arya, H., Verma, R., \& Bajpai, A. (2009). Saraca asoca (Ashoka): A Review. Journal of Chemical and Pharmaceutical Research, $1(1), 62-71$.

Qu, Y., Li, X., Lin, L., Wang, S., Guo, M., \& Dong, W. (2021). Study on the Adsorption of Nickel (II) in Water by Modified Dried Duckweed. E3S Web of Conferences, 245, 03083. https://doi.org/10.1051/e3sconf/202124503083

Rao, R. A. K., \& Kashifuddin, M. (2014). Kinetics and isotherm studies of Cd(II) adsorption from aqueous solution utilizing seeds of bottlebrush plant (Callistemon chisholmii). Applied Water Science, 4(4), 371-383. https://doi.org/10.1007/s13201-014-0153-2

Sundararaju, S., Manjula, A., Kumaravel, V., Muneeswaran, T., \& Vennila, T. (2020). Biosorption of nickel ions using fungal biomass Penicillium sp. MRF1 for the treatment of nickel electroplating industrial effluent. Biomass Conversion and Biorefinery. https://doi.org/10.1007/s13399-020-00679-0

Tan, J., Huang, Y., Wu, Z., \& Chen, X. (2017). Ion Exchange Resin on Treatment of Copper and Nickel Wastewater. IOP Conference Series: Earth and Environmental Science, 94, 012122. https://doi.org/10.1088/1755-1315/94/1/012122

Torab-Mostaedi, M., Asadollahzadeh, M., Hemmati, A., \& Khosravi, A. (2013). Equilibrium, kinetic, and thermodynamic studies for biosorption of cadmium and nickel on grapefruit peel. Journal of the Taiwan Institute of Chemical Engineers, 44(2), 295-302. https://doi.org/10.1016/j.jtice.2012.11.001

Uddin, M. K. (2017). A review on the adsorption of heavy metals by clay minerals, with special focus on the past decade. Chemical Engineering Journal, 308, 438-462. https://doi.org/10.1016/j.cej.2016.09.029

Villaescusa, I., Fiol, N., Martínez, M., Miralles, N., Poch, J., \& Serarols, J. (2004). Removal of copper and nickel ions from aqueous solutions by grape stalks wastes. Water 


\section{$11^{\text {th }}$ International Conference on Research in SCIENCE \& TECHNOLOGY}

14_16 May, 2021

Paris, France

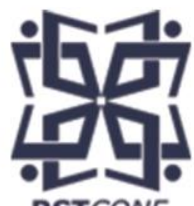

RSTCONF

Research, 38(4), 992-1002. https://doi.org/10.1016/j.watres.2003.10.040

Wang, X.-S., \& Qin, Y. (2006). Removal of Ni(II), Zn(II) and Cr(VI) from aqueous solution by Alternanthera philoxeroides biomass. Journal of Hazardous Materials, 138(3), 582588. https://doi.org/10.1016/j.jhazmat.2006.05.091 